\title{
DYNAMIC SPACES WITH SUBJECTIVE DEPTH. THE PUBLIC SPACE IN MONSOON AsIA
}

Espacios dinámicos con profundidad subjetiva. El espacio público en el monzón de Asia

\section{Akiko Okabe aokab@nifty.com University of Tokyo}

ABSTRACT: The largest human agglomerations in the world, headed by Tokyo, are found in Asia, especially in monsoon climate zones. If we start from the premise that they are 'cities', there must be something that makes them work as cities. In the present paper this 'something' is defined as 'public space'; taking Tokyo and Edo as an example, we explore this public space and how it differs from that of Europe's squares and streets.

The paper first analyzes the network of narrow alleys. The concept of $o k u$ is introduced to show how public space of subjective depth materializes in this web of narrow passageways.

Second, the question of public space corresponding to the scale of Asian megacities is explored. Hiroba, the Japanese term for square, can be understood as a dynamic process rather than a static, physical place. The hiroba emerges by hiroba-ing through spontaneous citizen action. Seasonal festivals amplify the effect of hiroba-ing and have a magic that temporarily transforms spaces into huge meeting places accessible to all.

The public space in monsoon Asia is a subjective space with a dynamic dimension toward $o k u$ that implies awe of nature.

KEYwords: square, Tokyo (Edo), social cohesion, alley, oku, hiroba-ing. 
RESUMEN: Las mayores aglomeraciones humanas del mundo, encabezadas por Tokio, se encuentran en Asia, especialmente bajo el clima monzónico. Si partimos de la premisa de que son «ciudades» también, debe existir algo que las hace serlo. En este artículo, ese algo se define como «espacio público»y, tomando Tokio y Edo como ejemplo, se explora el espacio público alternativo diferente a las plazas y calles europeas.

En primer lugar, se pone el foco de atención en la red de callejones estrechos. A través de la introducción del concepto de $o k u$, se revela que el espacio público de profundidad subjetiva se materializa como la red de callejones estrechos.

Además de los callejones estrechos, grandes ciudades en Asia deberían tener otra forma de espacios públicos acordes a su escala enorme. Hiroba, el término japonés para plaza, se puede entender como un proceso dinámico más que un lugar físico y estático. La hiroba emerge por las acciones espontáneas de los ciudadanos de hacer-hiroba. Los festivales estacionales aumentan el efecto de hacer-hiroba y tienen la magia de transformar cualquier lugar temporalmente en lugares de encuentro accesibles para todos.

El espacio público en Asia monzónica es un espacio subjetivo con dimensión dinámica hacia el oku que implica admiración por la naturaleza.

Palabras Clave: plaza, Tokio (Edo), cohesión social, callejón, oku, hacer-hiroba.

RESUM: Les majors aglomeracions humanes del món, encapçalades per Tòquio, es troben a Àsia, especialment sota el clima monsònic. Si partim de la premissa que són «ciutats» també, ha d'existir alguna cosa que les fa ser-ho. En aquest article, aquesta cosa es defineix com a «espai públic» i, prenent Tòquio i Edo com a exemple, s'explora l'espai públic alternatiu diferent a les places i carrers europeus.

En primer lloc, es posa el focus d'atenció en la xarxa de carrerons estrets. A través de la introducció del concepte d'oku, es revela que l'espai públic de profunditat subjectiva es materialitza com la xarxa de carrerons estrets.

A més dels carrerons estrets, grans ciutats a Àsia haurien de tenir una altra forma d'espais públics acords a la seua escala enorme. Hiroba, el terme japo- 
nès per a plaça, es pot entendre com un procés dinàmic més que un lloc físic i estàtic, ja que emergeix per les accions espontànies dels ciutadans de ferhiroba. Els festivals estacionals augmenten l'efecte de fer-hiroba i tenen la màgia de transformar qualsevol lloc temporalment en llocs de trobada accessibles a tothom.

L'espai públic a l'Àsia monsònica és un espai subjectiu amb dimensió dinàmica cap a l'oku que implica admiració per la natura.

Paraules clau: plaça, Tòquio (Edo), cohesió social, carreró, oku, fer-hiroba.

\section{Space of social cohesion}

L arge, densely populated human settlements are generally defined as cities. Thus, cities can be recognized in a biological sense as a kind of human habitat. ${ }^{1}$ They are 'nests' of humans. However, we believe cities are more than biological habitat. What differentiates cities from mere human agglomerations?

In the occidental world, from the agoras of the poleis to the modern squares of civic movements, streets and squares have forged cities out of simple human settlements. The presence of squares and streets is understood to turn mere agglomerations of humans into cities. In the western concept of the city, the term public space evokes squares and streets.

In contrast, two fundamental questions arise among Japanese urban researchers: firstly, do Japanese cities have 'squares'? And secondly, can we call large Japanese human settlements 'cities'?

The latter question has been endlessly discussed. In the Meiji era, foreign visitors to Japan, such as Isabella Bird, described Tokyo as a cluster of vil-

1. When residents depend mainly on agricultural activities they live in what are usually called villages. When residents have urban lifestyles, they live in cities. However, nowadays, it is quite common to have an urban lifestyle while living in a rural area and the difference between villages and cities is becoming less evident. 
lages rather than a city with unity, confirming the idea that Tokyo has never looked like a European city (Smith, 2006, pp. 201-237).

Nowadays, the largest human agglomerations in the world are found in Asia, especially in monsoon climate zones. ${ }^{2}$ If we start from the premise that they are cities, there must be something that makes the huge human agglomeration function as a city. In the present paper, this 'something' is defined as public space. Public space does not necessarily materialize as a square or a street. Even without squares, Japanese cities still have public spaces.

Public spaces are places that can be accessed and enjoyed by everybody for free and are not driven by the profit motive. Thus, public space ensures the social cohesion among a diversified citizenry and contributes to the sustainability of a city as a unit. ${ }^{3}$

Edo, former Tokyo, the pre-modern capital of Japan, had more than a million inhabitants at the beginning of the 18 th century and has been bigger than any European city for the last 200 years [fig.1]. However, the absence of exquisite squares or plazas and emblematic streets in Edo, in contrast to the occidental notion of the city, may strike the outsider as strange. If we follow the hypothesis described above, Edo must have the public space that makes it work as a city, a public space that is different from the European concept. This paper attempts to understand the alternative public space that prevails in monsoon Asia, focusing on Japan.

If we compare a bird's eye view of the morphology of Asian cities with European ones two clear differences emerge. Firstly, the 'grains' that make up the Asian cities look finer. Secondly, their physical borders are not clearly defined. These two characteristics are closely related to the monsoon climate.

2. Tokyo has often been compared with other large cities such as New York, London or Paris. Sassen (1991), for example, designated New York, London and Tokyo as the three global cities, defined by their considerable economic influence. However, Tokyo is physically too large for any direct comparison of its spatial form with that of other global cities in developed countries (Okabe, 2005, pp. 55-71).

3. «The city creates a situation where different things occur one after another and do not exist separately but according to their differences», Lefevbre, 1968.

The public space is the city. (Borja and Muxí, 2001) 


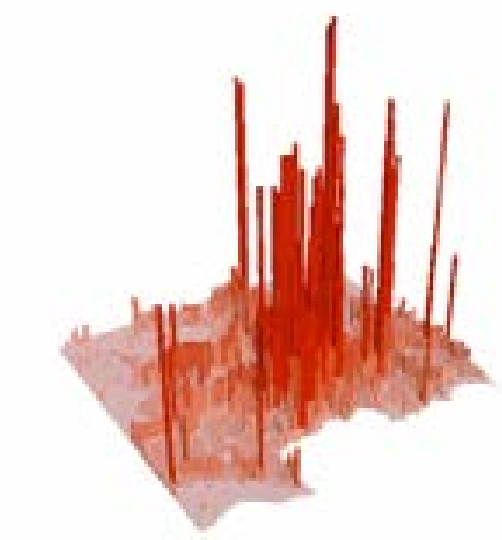

Jakarta

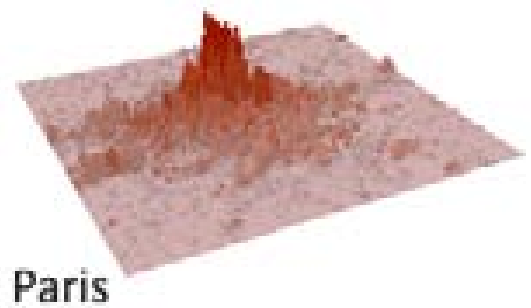

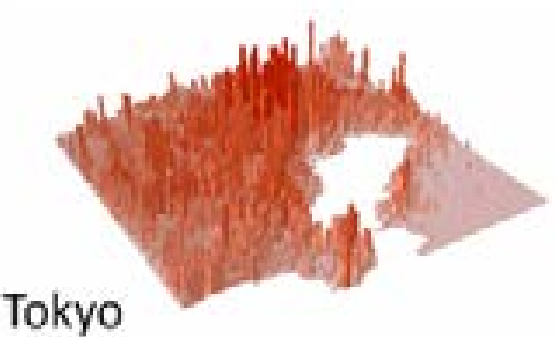

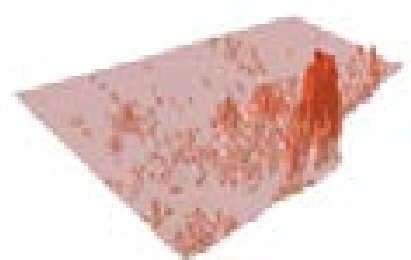

Barcelona

Figure 1. Population distribution in Asian and European cities. By Yuta Uchiyama.

\section{Network of narrow alleys}

The fineness of the city grains denotes the small size of the buildings. Traditional Japanese neighborhoods are well known for their narrow alleys and tiny wooden buildings. In the modern districts the buildings are also relatively small and the streets are narrow. If we consider the length of the exposed façade as the city's 'surface area', it is greater in Japanese cities because of the narrow alleys that flow through the entire city like the body's network of capillary vessels.

I am currently working in a self-organized neighborhood in Jakarta, Indonesia. This kind of neighborhood is known as a kampung (village in Indonesian); they are often slums, differentiated from the planned districts that date back to the colonial era. They are reminiscent of the typical 1960s neighborhoods in Japanese cities. Our kampung, called Cikini, is in the very center of Indonesia's capital city and 
is surrounded by redeveloped, modern districts. It has a density of around 1,000 people per hectare. Cikini was originally a village of between twenty and forty families scattered across a green area beside the river. But one consequence of densification is the loss of unbuilt areas. A very fine network of narrow alleys now covers the whole area, giving it four times the 'surface area' of the city's planned districts. The alleys are constantly full of women and children [fig.2]; this is where the women cook and chat together while their children play. The narrow alleys and small open spaces are relatively comfortable in the hot humid monsoon climate; they are cooler than large open spaces because of the shade. Families are used to living together with their relatives. The original family house is usually bigger, and its front yard and perhaps its living room are spaces shared by the relatives and are often open to everyone. The network of narrow alleys and spaces open to neighbors acts as a space for social relations and mutual help. They may be defined as public spaces adapted to the monsoon climate. By necessity, the shape of public space in the Asian monsoon culture tends to be endless, long, narrow and extended.

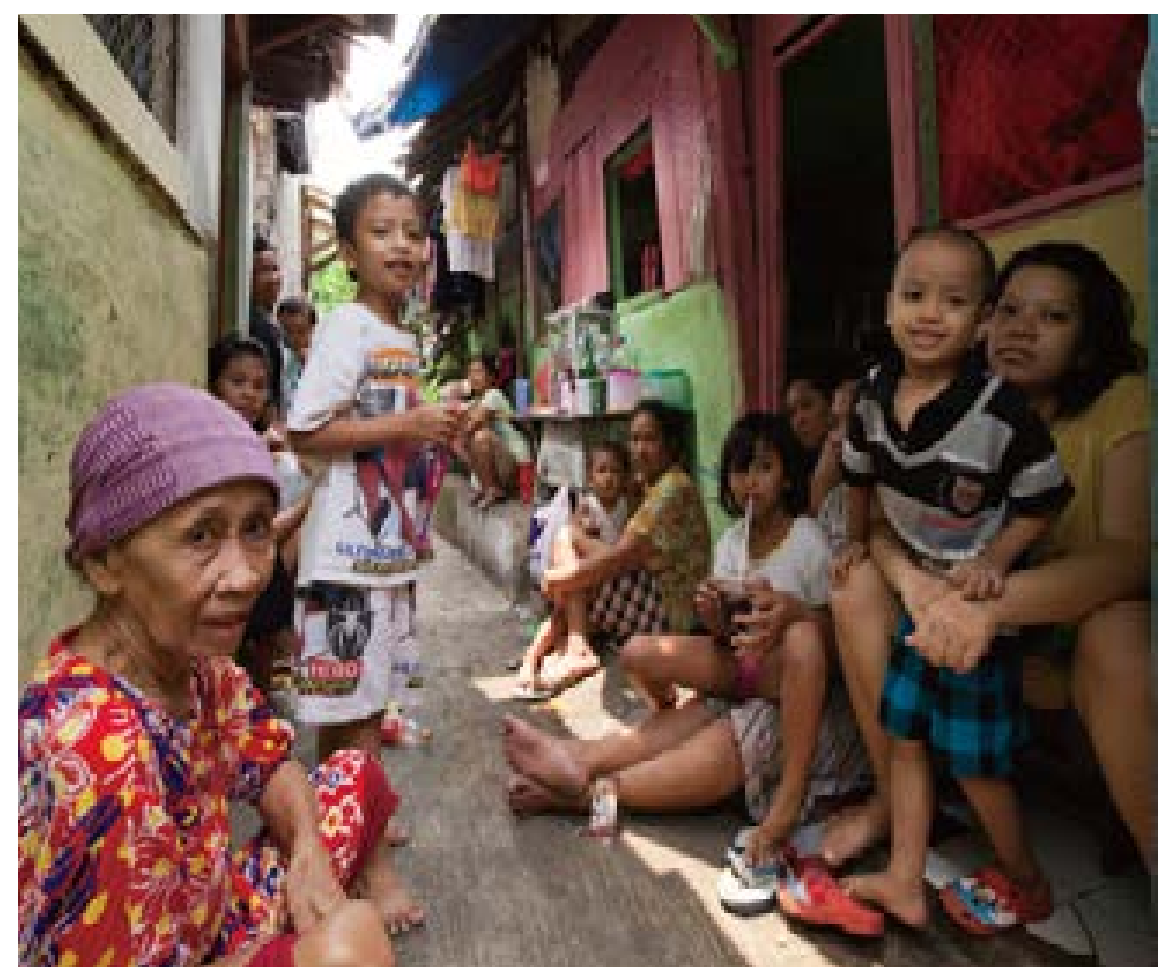

Figure 2. An alley in kampung Cikini. Photo: S. Asakawa. 


\section{The notion of oku}

Shrines have a notable presence in traditional Japanese settlements. They are well known as sites for religious ceremonies associated with the agricultural calendar, and some of them have become tourist attractions. Neighborhood communities of 50-100 households divide into five to ten groups that take turns to clean the shrine precinct every week. They hold monthly meetings in the meeting room next to the shrine. Many communities continue to observe these customs despite the severe aging of the population. Behind the commercialized religious festivals, everyday communal duties have survived and a multitude of small shrines still operate as spaces of social cohesion.

Shrine precincts do not have a center. The shrine is a metaphor of the approach to another world. When you pass through the symbolic gate, the torii, you are one step closer to another world. The sacred forest opens up in front of your path but it is not a goal to be reached; it is the spiritual path.
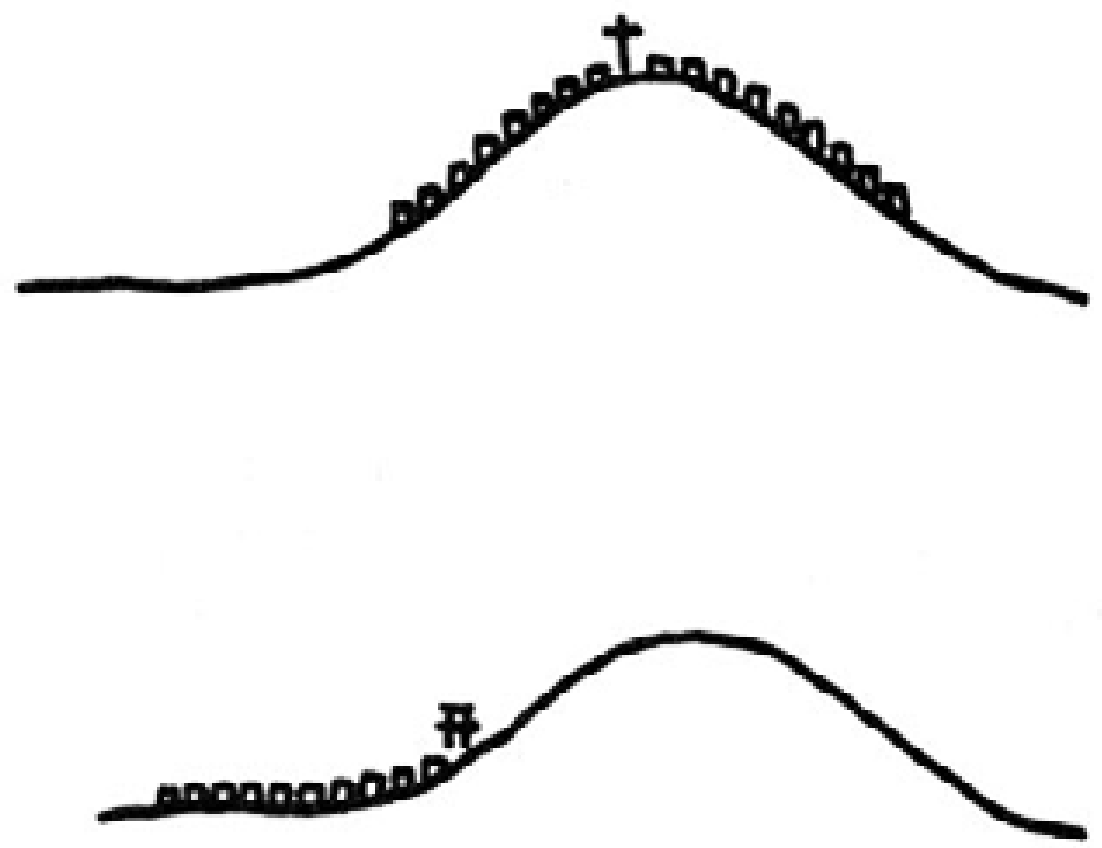

Figure 3. Concentric composition (above) and the path toward OKU (below), by F. Maki. Source: 槇文彦 他（1980）『見えがくれする都市』SD選書 
The Japanese architect, F. Maki, studied the special structure of Japanese shrines, which he attempted to interpret by introducing the concept of oku (Maki, 1978, pp.50-62) [fig.3]. Oku may be literally translated as 'deepness' or 'space with depth'. However, rather than the static state of space with depth, its meaning is one of a dynamic space that invites us into the deeper place. Traditional social cohesion can be attributed to the dynamics of $o k u$.

\section{Cities of 'fine grains'}

If we start from the premise that public space, as a space of social cohesion, is what keeps the city working as such, public spaces in Japanese cities are more likely to be found in the network of narrow alleys that invite people to go deeper and deeper toward oku rather than the central squares and main streets in European cities.

As mentioned above, the question of whether Japanese cities have squares is a perennial one. Ito said that the answer must be no if a square is understood as somewhere like the Greek agora or the Italian piazza (Ito, 1971). However, he stated that Japanese cities have a tradition to draw upon, "a device for creating relations among people, whether social, economic or political", the public space defined in this paper.

The conventional translation of square into Japanese is hiroba. Sand distinguishes hiroba from square by analyzing Ito's argument (Sand, 2013). Ito asserted that, historically, the hiroba in Japan had "existed by hiroba-ing, by virtue of being made a hiroba" through the spontaneous action of citizens. While the square is a tangible physical place, therefore, objective and static space, the hiroba-ing is a more subjective and dynamic concept, which is similar to what Harvey calls "commoning" (Harvey, 2008).

In everyday life, Japanese cities only have networks of fairly ordinary narrow streets. But in the festive season they are suddenly transformed into parade routes, which is when hiroba-ing occurs. The parade usually 
ends at the community shrine, which is a metaphor of oku. They are dynamic public spaces toward spiritual oku, or subjective depth.

While coarse-grained European cities have public spaces of objective magnitude, fine-grained Japanese cities have public spaces with subjective depth.

\section{Desakota: inseparable city-countryside}

Urbanized areas are difficult to identify in the Asian megacities of the monsoon zones. An urban area cannot be distinguished from a rural one by its physical appearance. In Japan, the standard measure of population density introduced to identify an urban area is a minimum of 40 people per hectare.

Monsoon zone megacities such as Tokyo, Bangkok, Dhaka and Jakarta are surrounded by paddy fields, whose productivity is extremely high compared with rural areas in Europe. In tropical climates rice may be harvested more than three times a year. Therefore in areas with a culture of rice cultivation, people with urban lifestyles can easily move to live in rural areas. Indeed, it is quite common for people to work weekdays in the city and weekends in the countryside. Spontaneous self-organized urbanizations sprang up everywhere during the years of population growth, which has resulted in enormous urban areas where the border with neighboring rural zones is unclear. Now motorization and increasing mobility are causing unplanned suburbanization even in less productive rural areas with colder climates, resulting in blurred urban areas.

McGee coined the term desakota (McGee, 1991, pp. 3-25) to describe this phenomenon in Jakarta. 'Desa' means countryside and ' kota' is city. It is impossible to identify the city, in the strict sense, of Tokyo. There is only the desakota of Tokyo, or the urban region of Tokyo including its rural hinterland. This is the reality of the city of Tokyo.

When we refer to Tokyo's public space, what should come to mind is the public space of Tokyo desakota that serves to sustain the monstrous human agglomeration of 30 million people as a unity across generations. 
This public space must extend beyond the network of intimate narrow alleys. Tokyo must have another public space with a different dimension-not just its picturesque narrow alleys-and much bigger than Europe's streets and squares.

\section{Public spaces in awe of nature}

In Edo, the streets looking toward Mt. Fuji were considered important [fig.4]. Mt. Fuji lies 50km from Edo; these streets may be considered as public spaces stretching over $50 \mathrm{~km}$. Sloping streets overlooking Edo bay were also accorded special status (Jinnai, 1985) [fig.5]. These were the public spaces of the Tokyo desakota. The streets were not special in themselves, despite being in largest agglomeration in the world at that time, but the broad panoramic view over the surrounding countryside made them important. Mt. Fuji and Edo bay materialized $o k u$ and invited people toward oku. The spiritual and subjective depth amplified by their imagination shaped the emblematic public space as a feeling shared among the citizens of Edo. 


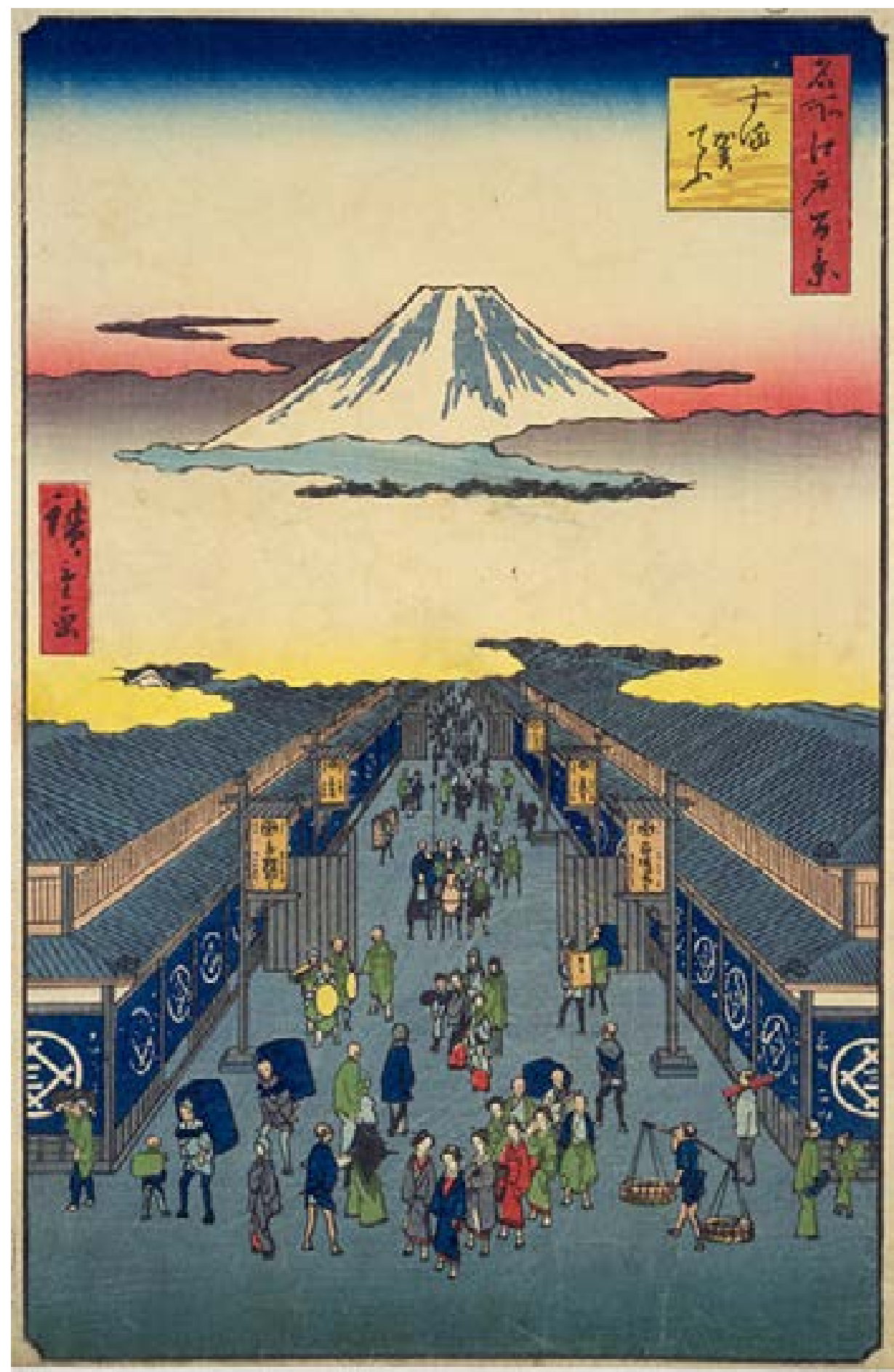

Figure 4. Surugacho, Hiroshige. An Edo street overlooking Mt. Fuji.

Source: 広重 『名所江戸百景 : 駿河町』 
In former Edo and also now in Tokyo, cherry blossom has had the magic to temporarily transform everywhere into spontaneous meeting places accessible to everyone. The cherry blossom triggers the hiroba-ing, hopefully giving rise to a space of solidarity among citizens.

It was said that when the cherry blossom bloomed, it was for everybody to enjoy, regardless of social class, even in the feudal period of Edo. The Sumida River fireworks have also held the magic of hiroba-ing since the Edo period. The public space of Edo had a physical characteristic that is tangible by hiroba-ing only on certain occasions. It has been associated with awe of nature and is connected to eternal oku. Subjectively, it is felt as a colossal, endless and timeless space, the public space that may have worked to sustain the wider city of Tokyo as a unity across generations.

Global competition among cities is now becoming fierce. If we ignore the question of natural disaster, Tokyo is in a strong position, but if it is taken into account, Tokyo slips down the ranks. Natural disasters might also be considered as public spaces: devastating earthquakes and typhoons have certainly strengthened social cohesion in the past. Oku has been established as a spatial interpretation of natural disaster.

If we regard vast places of habitat in monsoon Asia as 'cities', we should reexamine the notion of public space. The public space can go beyond the objective space of static squares and streets, from microcosms of hirobanized narrow alleys to metaphorically colossal streets with Mt. Fuji as if it were a statue in the square. They are subjective spaces with a dynamic dimension toward $o k u$ that implies awe of nature. 


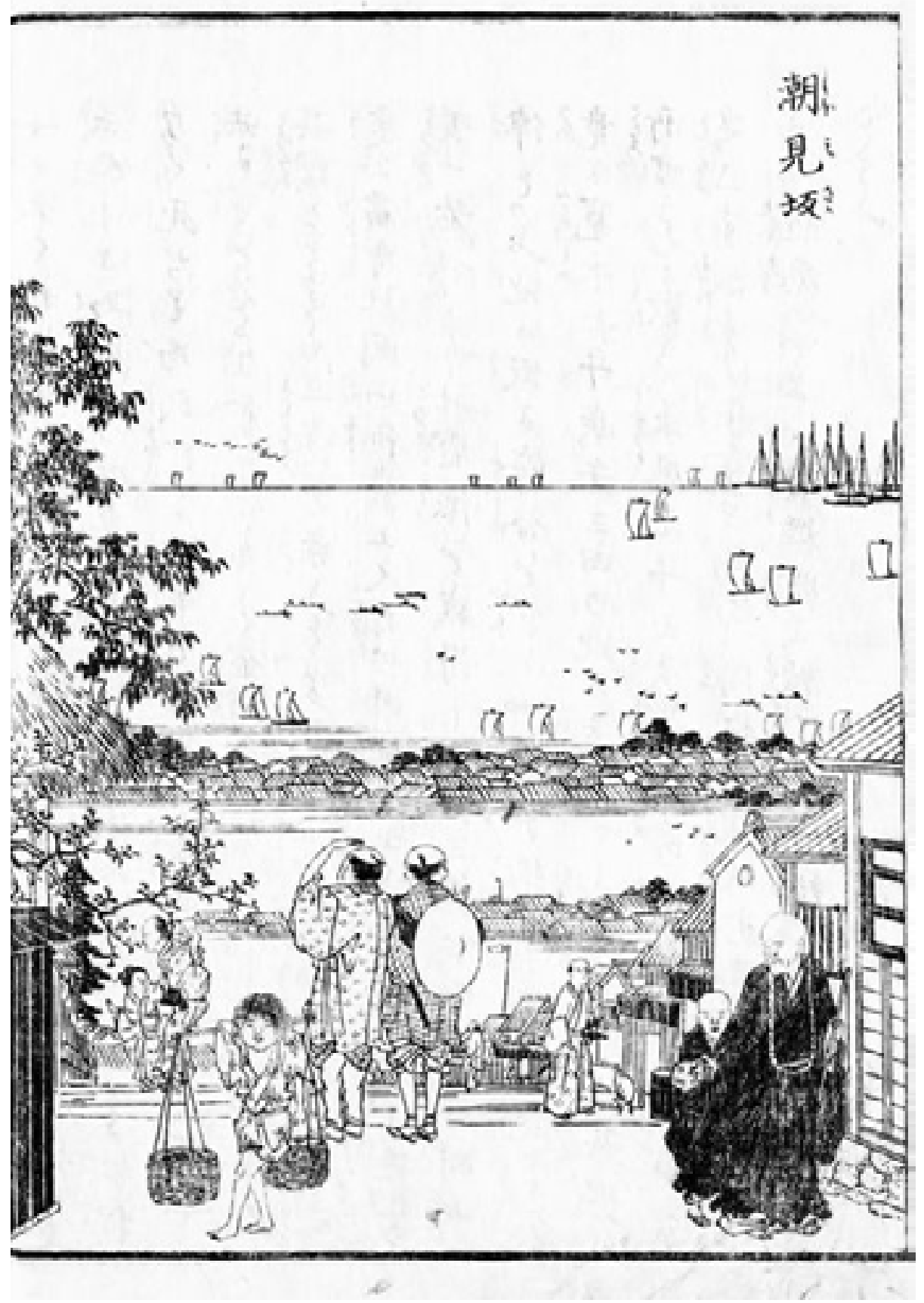

Figure 5. Shiomi-zaka. Sloping street overlooking Edo bay. Source:『江戸名所 図絵』 


\section{References:}

BorJa, J. \& Muxí, Z. (2001). L'espai public: ciutat i ciutadania. Barcelona: Diputació de Barcelona.

Harvey, D. (2012). Rebel Cities: From the right to the city to the urban revolution. New York: Verso.

伊藤ていじ他・都市デザイン研究体（1971）。「日本の広場」『建築 文化』n298 In Japanese only: Ito, Teiji et al., Nihon no Hiroba.

陣内秀信 (1985).『東京の空間人類学』筑摩書房 In English: Jinnai, Hidenobu (1995) Tokyo: A Spatial Anthropology. Berkley: University of California Press.

Lefevbre, H. (1968). Le Droit à la ville. Paris: Anthropos.

槇文彦（1978）。「日本の都市空間と『奥』」『世界』397号 146-162 頁 In English: Maki, Fumihiko (1979) Japanese City Spaces and the Concept of Oku, Japan Architect, no. 264, pp.50-62.

McGeE, T. G. (1991). "The Emergence of Desakota Regions in Asia: Expanding a Hypothesis». The Extended Metropolis: Settlement Transition in Asia (Honolulu: University of Hawaii Press), pp. 3-25.

岡部明子 (2003).「公共空間を人の手に取り戻す一欧州都市再生の原 点」宇沢弘文・薄井充裕・前田正尚 編著（2003）『都市の ルネッサンスを求めて、社会的共通資本としての都市1』東 京大学出版会11-38頁 In English: OKABE, A. (2011). «Reclaiming public space for people: the roots of European urban regeneration». DBJ Research Center on Global Warming Discussion Paper Series, No. 38.

Окаве, А. (2005). «Towards Spatial Sustainability of City-regions: A Comparative Study of Tokyo and Randstad». In Jenks, M. AND DempSeY, N. (eds), Future Forms and Design for Sustainable Cities. Oxford: Architectural Press, pp. 55-71.

SAND, J. (2013). Tokyo Vernacular: Common Spaces, Local Histories, Found Objects. California: University of California Press.

SAssen, S. (1991). The Global City: New York, London, Tokyo. Princeton, nJ: Princeton University Press.

SMITH, H. D. (2006).「村〈ヴィレッジ〉としての東京：変転する近代 日本の首都像(Tokyo as a 'Village': Changing Perceptions of Japan’s Capital City)」『シリーズ 都市・建築・歴史 6 : 都市文 化の成熟』東京大学出版会 pp. 201-237. 